\title{
The Emergence of Engineering as a Profession in Modern India*
}

\author{
Aparajith Ramnath**
}

(Received 15 May 2018; revised 23 May 2018)

\begin{abstract}
This paper gives a brief overview of the rise of engineering as a profession in modern India. It describes how, from the turn of the twentieth century to the coming of Independence, the profession expanded and was transformed - from one dominated by expatriate British engineers in government services, to a more diversified one in which Indian engineers played an increasingly important role, along with engineers from private industry. It examines these processes of Indianisation and industrialisation against the backdrop of political change, particularly in interwar India.
\end{abstract}

Key words: Engineers, Engineering, Indianisation, Industrialisation, Profession.

\section{INTRODUCTION}

In 1925, a letter from an anonymous engineer appeared in the journal Indian Engineering. 'Of the numerous public bodies in this country holding important and responsible positions', he wrote, 'there are few so characteristically modest as the members of the engineering profession, both European and Indian'. They were acknowledged neither by the state nor 'by a certain class of extremist politicians whose sole aim is destruction, not construction'. He went on:

'Where would India be now were it not for its railways and gigantic irrigation works? ... What would the various industries which are in existence have done without its engineers; they are the backbone of them'(C.E., 1925).

Engineers were not only at the heart of the Indian government bureaucracies in the early twentieth century, but also pivotal to the newly emerging large-scale industries. Yet they were members of a profession undergoing a significant transformation, and the letter from 'C.E.' hints at the anxieties that accompanied it. Engineers in India were increasingly conscious of a collective identity. 'Native' Indian engineers were becoming more prominent, albeit gradually. They worked in the midst of continuous political change, as the end of Empire became a real possibility.

What drove this transformation, and why was it significant? What does it tell us about the culture of engineering in modern India? In order to answer some of these questions, we must begin with a brief glance at the preceding centuries.

\section{BACKGROUND}

The earliest group of people in India to identify themselves by the English term 'engineer' was the East India Company's corps of military engineers in the seventeenth and eighteenth centuries. These men were tasked with building roads, bridges and fortifications required by the army (Fenwick, n.d.). In the mid-nineteenth

\footnotetext{
* A version of this paper was delivered by the author as the IWA Endowment Lecture 2018, Government Museum, Chennai. Versions of some passages have previously appeared in the author's book (Ramnath, 2017) and his online article (Ramnath, 2016). **Assistant Professor, Ahmedabad University, B-32, Hub 3 (Basement), GICT Building, Ahmedabad University Central Campus, Navrangpura, Ahmedabad - 380009. Email: apconf@gmail.com
} 
century, as colonial rule began to consolidate itself, a separate, civilian department called the Public Works Department (PWD) was established. The PWD, the fast-growing railways, and the military accounted for most of the engineers working in India at this time-and they were nearly all imported from Britain (Ramnath, 2017, pp. 5859, p. 95).

The engineers initially sent out to India to staff the PWD were trained by the traditional British method, by apprenticeship to a practising engineer (Cuddy, 1980, p. 63). In 1871, a special college was set up at Cooper's Hill near London to train engineers for the Indian PWD (Ibid., chapter 3). Well into the twentieth century, topranking engineers in the Indian government came from Britain as a rule. As calculated from government records for 1922, for instance, Cooper's Hill alumni accounted for 62 per cent of officers in the rank of Chief Engineer, and 53 per cent of Superintending Engineers (Government of India, 1922).

There were of course Indians too, trained at the engineering colleges of Roorkee, Sibpur (near Calcutta), Guindy (Madras), and Poona, all dating from the nineteenth century. But these Indians were mostly employed as subordinates, draughtsmen or overseers. Some of them were recruited as officers, but they formed a cadre that had lower status, pay, and benefits than the engineers imported from Britain — although they did similar kinds of work (Ramnath, 2017, chapter $3)$.

\section{The Culture of Public Works ENGINEERING}

Engaged as they were in building the roads, buildings and irrigation works of Victorianera India, engineers were seen as important representatives of the imperial power-and their training was planned accordingly. As the Spectator of London declared in the year 1870:
The ideal Engineer for India is a man who will take $£ 1000$ a year as his average income for life, and insist that all under him shall be content with their wages; who can build anything from a Tanjore tank as big as the lake of Lucerne to a cloacae for the last new stockade; who will regard an offer of a commission from sub-contractors as a deadly insult; who can keep accounts like a bank clerk . . .(quoted in Black, 2009, p. 232).

In other words, an engineer was supposed to be two things. First, he must be a noble, incorruptible gentleman. Second, he must be a generalist able to take on a very wide range of tasks. A typical government engineer's duties were managerial as much as technical: he had to oversee accounts, order materials, manage contractors, examine designs, and conduct inspections (Ramnath, 2017, chapter 3).

The college at Cooper's Hill, which was meant to produce exactly such engineers, had a deep influence on the PWD_its graduates emanating from a small London suburb to fan out across the Indian provinces year after year. And Cooper's Hill engineers were trained to be gentlemen. Even the entrance exam included English history and classical languages apart from maths and science subjects. In the college, students worked hard, but also had an Oxbridge-type lifestyle: billiards, wine, formal meals (Cuddy, 1980, pp. 171-2). Col. George Chesney, the first President of the college, said that PWD engineers should be 'not only good engineers but religious men, at any rate Christians in feeling and profession' (quoted in Ibid., p. 200).

In later years, Cooper's Hill was closed, and graduates of other British engineering colleges were chosen for the Indian PWD by a selection board (India Office, 1921, p. 254). Here too gentlemanliness was emphasised. This is illustrated by the interview of Geoffrey Hall, a graduate of the Central Technical College in London. He was interviewed at the India Office around the year 1910. His memoir describes the occasion vividly. Hall says he 'spent weeks 
mugging up engineering formulae, details of cement and brick manufacture and the weights and composition of materials'. On the actual day, he was asked what sports he played at school, how he spent his leisure hours, whether he danced and rowed. He was asked next to nothing of the material he'd studied. '[A]nd so much', he wrote, 'for all my weeks of cramming!' (Hall, 1947, vol. 1, pp. 40, 41, and 43). Hall's social and sporting accomplishments and his institutional pedigree clearly carried as much weight with the committee as his technical qualifications.

Once they took up their posting in India, engineers took on the role of sāhibs who lorded it over their circles and divisions, even acting as magistrates. There was much riding around the countryside on horseback, sik $\bar{a} r$ or hunting expeditions, and a lifestyle centred around bungalows and a dozen different kinds of servant (see for instance Hall, 1947; Bourne, n.d.). Life could be tough at times, but it was prestigious.

But what was it like being an Indian engineer? The Indians who made it to the engineering services, whether in the state-run railways or in the PWD, were were also moulded along similar lines. Their job came with great prestige precisely because of their status as government administrators. The perks included a stable job, government housing, a retinue of servants and subordinates, and government honours for long-serving officers (Reddy, 1975; Visvesvaraya, 1951). K L Rao, a famous hydraulic-engineer-turned-minister, recorded in his memoirs that he trained as an engineer in the pre-Independence period on the advice of his brother, who was impressed by the lifestyle of irrigation officers and the boats in which they travelled in the Masulipatnam canal, not far from Rao's village (Rao, 1978, p. 3).

But very few Indian engineers achieved high rank in the years before World War I. Even the legendary figure Sir Ganga Ram, who is known as the father of modern Lahore, retired from government service as an Executive Engineer (Yorkshire Post, 1927). Sir M Visvesvaraya, the patron saint of Indian engineers today, took early retirement from the Bombay PWD, anticipating that he would not be made Chief Engineer at the time he deserved (Visvesvaraya, 1951, p. 32). Indian engineers at this time were conscious of being judged all the time. British expatriate engineers often had a critical attitude towards their Indian colleagues. It is worth noting that they normally criticised the Indians not on the basis of their technical ability; instead they argued that they did not possess the integrity, courage and resourcefulness of their European colleagues (Ramnath, 2017, chapter 3). In the railways, which were seen as crucial to military strategy and security, it was Indian engineers' loyalty to the Empire that was sometimes seen as suspect (Ibid., chapter 4).

Naturally this state of affairs was a tense one, and there was bound to be some conflict within the profession. Nevertheless, for various historical reasons, the process of change began to quicken in the years between World War I and World War II. Nationalist politicians set up a steady demand for more technical education for Indians. As they began to win a greater share of power in the legislative process, the process of Indianisation - or the replacement of Europeans in government service by suitably qualified Indians-became a very important political demand. It was a demand that carried a certain moral weight, as Indian participation in World War I had been bought at least partly with the promise of a greater role for them in the post-war government (Ibid., chapter 1). Unsurprisingly, Indianisation was not an easy or uncontested process. Some expatriate engineers and policymakers feared a descent into chaos, an undoing of what they saw as the accomplishments of British engineering in India. In Britain, some aspiring engineers were growing reluctant to undertake a career in India if it involved serving under Indian engineers. As a result, the colonial 
government adopted a policy of cautious Indianisation, generally proceeding slower than it had promised (Ibid., chapters 3, 4).

\section{INDIANISATION, INDUSTRIALISATION, AND Professional Consolidation}

Yet change was afoot, and not only in the realm of government services. Circumstances during World War I opened the colonial government's eyes to the need for developing India's industrial capabilities, and in the years between the World Wars the government relaxed its laissez faire stance and began to introduce some proindustrial policies. Chief among them were protective tariffs for selected Indian industries like steel, paper, and sugar. Membership statistics of professional societies indicate a corresponding rise in the number of engineers in industrial roles in this period. In 1900 the profession had been dominated by government employees; by the 1940s a substantial proportion of engineers were working in private industry, and the proportion of Indians in the profession had risen considerably (Ibid., chapters 1, 2).

Many of the enterprises in this growing industrial sector were owned by Indian business families. An examination of these industries' modus operandi in garnering technical know-how and recruiting technical experts demonstrates that engineering was not only about dams, bridges, and railways; it was not entirely a story of the imperial metropolis and the dependent colony. The Tatas, who started their iron and steel factory in Jamshedpur in the first decade of the twentieth century, engaged the services of an American consulting engineer, C P Perin, to design their factory, and employed a series of his countrymen as general managers. Technical personnel were recruited from Britain, from Germany, from the steel mills of Gary, Indiana, and of course, from India itself. Also among the experts hired were Indians who had gone abroad - to the US, to Germany — to study industrial technologies. The
Tatas even set up their own technical institute in the 1920s, where Indian graduates were put through an intense practical course of training before being recruited to the steel factory. Already the massive popularity of this avenue of employment was in evidence, as applications to this institute poured in from all over the country (Ramnath, 2017, chapter 5).

The culture of engineering in the Tata steel works was very different from the gentlemanly ideal. Here physical fitness, a willingness to work long hours on the shop floor, and a lack of pretentiousness were the prized attributes (Ibid.). John Keenan, an American general manager of the firm, recounted with approval the story of an Indian technical expert who, on being insulted by a Yorkshireman in the steel works, 'landed a haymaker on the foreman's jaw, putting him out for the count' (Keenan, 1943, p. 134).

What, then, was the common ground between the stately government engineer and the dynamic industrial technologist? For various reasons, they did view themselves as part of a common profession. Let us look briefly at professional institutions. Until World War I, engineers working in India (both Britons and Indians) aimed to join one or more of the three prestigious professional societies in London: the Institution of Civil Engineers, the Institution of Mechanical Engineers, and the Institution of Electrical Engineers. These Institutions had governmental sanction, codes of conduct, and minimum qualifications (in terms of education and experience) for membership. They discussed technical papers and published the proceedings in journals (see Buchanan, 1985). Increasingly, engineers in India began to feel cut off from these societies, and formed a new one, the Institution of Engineers (India) - or IEI-headquartered in Calcutta, in 1920 (Nandy [ed.], 2002, pp. 5-6; Brady, 1921). Here public works engineers, railway engineers, and engineers from industry met regularly and discussed their work. 
The new professional institution helped engineers in India forge a common identity. They evolved a common language of economic nationalism and the role of engineers in promoting the country's development. Unlike its cousin institutions in London, the IEI was not subdivided by branch of engineering: mechanical and electrical engineers mingled with civil engineers under its auspices, just as British engineers mingled with Indian engineers. It was perhaps here that for the first time the notion of an Indian identity for the engineering profession was developed (Ramnath, 2017, chapter 2). Unusually for an institution in the pre-Independence era, eight of the first 22 presidents of the IEI were Indian (Nandy, 2002, pp. 75-7). The Institution was soon recognised as the voice of Indian engineering. In 1923 the IEI's Council functioned as the Indian National Committee for the International Electrotechnical Commission (IEI, 1965, p. 6). By 1928, the Institution's membership had crossed a thousand, and it had begun to hold its AMIE (Associate Member of the Institution of Engineers) Examination, which was later recognised as equivalent to an engineering degree (IEI, 1930, p. 3; IEI, n.d.).

By the end of the 1940s, the pressures of World War II and the coming of Independence had further accelerated the process of Indianisation, so that relatively few British engineers were left in India. In that decade, all except one President of the IEI were Indians (Ramnath, 2017, passim and p. 85).

\section{Conclusion}

Many questions remain to be explored. How did the culture of engineering change with the establishment of the Indian Institutes of Technology (IITs) in the post-Independence period? What socio-economic strata have most engineers come from, and has there been a transformation in this background over recent decades? In other words, to what extent have careers in engineering enabled social mobility? In the pre-Independence period the profession was almost entirely male, but that has changed dramatically since. The role and experience of women in the engineering profession is therefore another very important area for future research.

For now, our study of engineering in the pre-Independence period has interesting implications for our perspectives on Indian history more generally. It reminds us, for instance, that while the interwar years were dominated by ideological debates and the politics of the freedom struggle, they co-existed with a bustling world of industry, one in which engineering professionals were negotiating their place in society and vis-àvis one another. Further, World War I emerges as a very important milestone-perhaps as important as 1947. If several of the major Nehruvian science and technology projects had their roots in the interwar period, the interest in engineering as a profession-including its professed role in building the nation - was already in evidence from the 1920s. Finally, India in the period from World War I to 1947 is best understood as a polity in transition: neither entirely colonial, nor yet completely national, but with elements of both.

\section{BiBLIOGRAPHY}

Black, John. The military influence on engineering education in Britain and India, 1848-1906, Indian Economic and Social History Review, 46, 2 (2009): 211-39.

Bourne, Hilda, It Was Like This, bound typescript memoir (n.d.) in J.M. Bourne Papers, CSAS Archives (Centre of South Asian Studies), Cambridge.

Brady, Hugh W. The Origin, Character and Prospects of the Institution, Journal of the Institution of Engineers (India), 1 (September 2001): 30-37.

Buchanan, R A. Institutional Proliferation in the British Engineering Profession, 1847-1914, Economic History Review, New Series, 38, 1 (February 1985): 42-60.

'C.E.', Letter to the Editor, Indian Engineering, 7 November 1925, p. 260.

Cuddy, Brendan P. The Royal Indian Engineering College, Cooper's Hill, (1871-1906): A Case Study of State 
Involvement in Professional Civil Engineering Education, PhD thesis, London University, 1980.

Fenwick, S C. Corps History - Part 10: Indian Sappers (1740-1947), website of the Royal Engineers Museum, Kent, http://www.remuseum.org.uk/corpshistory/ rem_corps_part10.htm, last accessed 4 June 2008 .

Government of India, Public Works Department. Classified List of Establishment, corrected up to 30th June 1922, Superintendent Government Printing, India, Calcutta, 1922. British Library, Asia, Pacific and Africa Collections (APAC): IOR/V/13/220.

Hall, G F. 'All in the Day's Work'. Typescript, 2 volumes, 1947. British Library, Asia, Pacific and Africa Collections (APAC): Mss Eur D569/1 and D569/2.

[India Office]. India Office List for 1921, Harrison and Sons, Ltd., London, 1921.

Institution of Engineers (India) [IEI]. Journal of the Institution of Engineers (India), Vol. IX, May 1930.

Institution of Engineers (India) [IEI]. Yearbook 1964-65, IEI, Calcutta, 1965.

Institution of Engineers (India) [IEI]. Historical Events of the Institution, at http://www.ieindia.org/archives/ history.htm, n.d., last accessed 31 January 2009.
Keenan, John L. [with Lenore Sorsby]. A Steel Man in India, Duell, Sloan and Pearce, New York, 1943.

Nandy, H. (ed.) IEI Marches On, A.K. Poothia for Institution of Engineers (India), Kolkata, 2002 [1996].

Ramnath, Aparajith. The Birth of an Indian Profession: Engineers, Industry, and the State, 1900-47, Oxford University Press, Delhi, 2017.

Ramnath, Aparajith. The historical roots of our Engineering obsession. thREAD, 15 September 2016. https:// www.thehindu.com/thread/reflections/the-historicalroots-of-our-engineering-obsession/article 14639373.ece, last accessed 15 November 2018.

Rao, K L. Cusecs Candidate: Memoirs of an Engineer, Metropolitan Book Co., New Delhi,1978.

Reddy, D V. Inside Story of the Indian Railways: Startling Revelations of a Retired Executive, M. Seshachalam \& Co, Madras, 1975.

The Yorkshire Post and Leeds Intelligencer. Sir Lala Ganga Ram, 11 July 1927, p. 14.

Visvesvaraya, M. Memoirs of My Working Life, M. Visvesvaraya, Bangalore, 1951. 